\title{
Research on the construction plan layout of the combined Hydrogen and CNG refueling station
}

\author{
Xiaotong Wang ${ }^{1, *}$, Nana Liu $^{2}$ \\ ${ }^{1,2}$ Department of Intelligent Manufacturing Engineering, Chongqing College Of Architecture And Technology, Shapingba District, \\ Chongqing, China
}

\begin{abstract}
Research on fuel cell hydrogen refueling stations is mostly concentrated on newly-built stations, and there are few studies on the combined hydrogen and CNG refueling stations. The construction plan of combined hydrogen and CNG refueling stations is conducive to planning and layout, solving the difficulties in land use of hydrogen refueling stations, and reducing construction investment and operating costs. This paper analyzes the feasibility of the combined station construction, studies the construction plan and scale of the combined station, and proposes its general layout plan.
\end{abstract}

\section{Preface}

The energy shortage and environmental pollution caused by automobiles are becoming increasingly prominent. The promotion of hydrogen refueling stations is an important measure and development trend to alleviate the contradiction between fuel supply and demand, reduce exhaust emissions, improve the atmospheric environment, and promote technological progress in the automotive industry.

In large and medium-sized cities with convenient transportation, the available land is tight, It is difficult to select a site for a new hydrogen refueling station, and construction is hindered. Zhenhong Lin proposed that the location of the hydrogen refueling station can be determined based on the "fuel return" problem. Due to the difficulty in selecting locations in urban areas, it is necessary to expand the refueling and storage scale of hydrogen refueling stations[1]. Hyunjoon Kim proposed that the Republic of Korea plans to build hydrogen fuel stations across the country, and through mathematical models and demand, the country's hydrogen refueling station deployment plan is derived [2]. At present, most of the research on fuel cell hydrogen refueling stations is focused on newly-built stations, and there are few studies on combined hydrogen and $\mathrm{CNG}$ refueling stations.

Adding hydrogen refueling function in $\mathrm{CNG}$ (Compressed Natural Gas) filling station can effectively solve the planning layout and land use problems of hydrogen refueling stations. It can not only reduce construction investment and operating costs, but also help jointly promote the maturity and development of the hydrogen fuel cell vehicle and natural gas vehicle market.

\section{Feasibility study of the combined station}

\subsection{Market demand for hydrogen fuel cell vehicles}

From 2016 to 2019, the sales of hydrogen fuel cell vehicles in China were 629, 1275, 1527 and 2,737 respectively. In 2020, the development of fuel cell vehicles reaches a new level. China's hydrogen fuel cell vehicles are mainly used in the field of commercial vehicles, namely passenger vehicles and freight vehicles. Passenger vehicles have fixed driving routes, and the types of vehicles in the passenger market mainly depend on the planning of the local government. They are highly driven by the government and are conducive to the development of hydrogen fuel cell vehicles. In the field of freight transportation, hydrogen fuel cells have obvious advantages over diesel engines and lithium batteries due to their long cruising range, low emissions, and fast hydrogenation speed.

In recent years, CNG vehicles have been well promoted and applied in various provinces and cities in China, especially in the field of commercial vehicles such as buses. Because the refueling location is relatively fixed, the combined construction of hydrogen and $\mathrm{CNG}$ refueling stations is suitable.

\subsection{Similar properties of hydrogen and natural gas}

The most important component of natural gas is methane $\left(\mathrm{CH}^{4}\right)$, and the methane content of general natural gas for vehicles is more than $90 \%$. Hydrogen and natural gas have similar properties. They are both flammable, explosive, 
combustible gases with a density lower than air, and both are clean energy sources. The explosion limit of methane is between $5 \sim 15 \%$, and the explosion limit of hydrogen is wider, between $4.0 \%$ and $75.6 \%$.

\subsection{Breaking the development bottleneck of hydrogen refueling station}

Hydrogen refueling stations for urban public transport and logistics services need to be built in or near the city. The urban population is dense and the available land area is tight, making it difficult to develop new hydrogen refueling station land. To solve this problem, it is very necessary to explore the combined construction technology of hydrogen and gas refueling station.

With the addition of traditional energy companies, integrated car service stations for gas, hydrogen, refueling, and charging will become one of the future trends. Hydrogen refueling stations are built on existing gas refueling stations, which is considered to be a better construction method at present. The existing gas refueling stations have the land area and safety spacing requirements for the combined construction of hydrogen refueling stations, which can reduce the planning land approval process. Both hydrogen and natural gas are hazardous chemicals, which is conducive to the operation, management and supervision of energy companies and regulatory authorities.

\section{Construction plan of the combined station}

\subsection{Construction mode}

The hydrogen production equipment in the station needs to be opened and closed frequently, which is difficult to operate and manage, and covers a larger area. China's hydrogen refueling stations mainly produce hydrogen outside the station and transport it to the station by long tube trailers. After the hydrogen from the long-tube trailer is unloaded by the unloading column, part of it is pressurized by the compressor and stored in the hydrogen storage tank, and the other part is directly supplied to the hydrogen dispenser. Although the transportation efficiency of liquid hydrogen is higher than that of gas hydrogen [3], due to the insufficient resources of liquid hydrogen in China, it is currently only used in a small amount in the United States and Japan. The combined station studied in this paper uses hydrogen long-tube trailers as its source.

\subsection{Design scale of the combined station}

The grading of the combined hydrogen and CNG refueling station construction shall comply with the relevant regulations [4], specific data refer to Table 1 . In the city built-up areas, it is recommended to build secondary combined hydrogen and gas refueling station. The total capacity of hydrogen storage tanks is no more than $1000 \mathrm{~kg}$, and the capacity of single tanks is no more than $500 \mathrm{~kg}$.
The total volume of $\mathrm{CNG}$ storage facilities in $\mathrm{CNG}$ secondary filling station is no more than $12 \mathrm{~m}^{3}$, and the total volume of $\mathrm{CNG}$ storage facilities in pipeline gas refueling station is no more than $18 \mathrm{~m}^{3}$.

The station is equipped with fixed hydrogen storage cylinder group and a movable long-tube hydrogen trailer. Fuel cell vehicles are developing rapidly, and the best solution for construction is to park two long-tube hydrogen trailers to meet peak demand.

However, the installation of two hydrogen trailers will cause the total hydrogen storage in the station to exceed $1000 \mathrm{~kg}$, and the level of the combined station will be increased from level 2 to level 1, and it cannot be built in urban built-up areas [4]. The design of this paper uses a long-tube hydrogen trailer to park in the station. At present, the design supply scale of CNG pipeline gas filling station is $2 \sim 4 \times 10^{4} \mathrm{~m}^{3} / \mathrm{d}$, the design supply scale of the $\mathrm{CNG}$ secondary filling station is $1 \sim 2 \times 10^{4} \mathrm{~m}^{3} / \mathrm{d}$. In this paper, the hydrogen refueling station and the most common design supply scale of CNG station are used to build. In this way, the research results are more meaningful.

Table 1. The classification of the combined hydrogen and CNG refueling station

\begin{tabular}{|c|c|c|c|c|}
\hline \multirow[t]{2}{*}{ level } & \multicolumn{2}{|c|}{$\begin{array}{c}\text { Hydrogen storage tank } \\
\text { capacity }(\mathrm{kg})\end{array}$} & \multirow{2}{*}{$\begin{array}{l}\text { Total volume } \\
\text { of gas storage } \\
\text { facilities of } \\
\text { pipeline gas } \\
\text { filling stations } \\
\left(\mathrm{m}^{3}\right)\end{array}$} & \multirow{2}{*}{$\begin{array}{c}\text { Total volume of } \\
\text { gas storage } \\
\text { facilities of } \\
\text { CNG secondary } \\
\text { filling station } \\
\left(\mathrm{m}^{3}\right)\end{array}$} \\
\hline & $\begin{array}{l}\text { The total } \\
\text { capacity }\end{array}$ & $\begin{array}{c}\text { Single tank } \\
\text { capacity }\end{array}$ & & \\
\hline Level 1 & $\begin{array}{c}1000<\mathrm{G}< \\
4000\end{array}$ & $\leq 1000$ & \multirow[t]{2}{*}{$\leq 12$} & \multirow[t]{2}{*}{$\leq 18$} \\
\hline Level 2 & $\mathrm{G} \leq 1000$ & $\leq 500$ & & \\
\hline
\end{tabular}

\section{Construction layout plan of the combined station}

\subsection{Requirements of general layout}

The combined Hydrogen and CNG refueling station is a Class A fire hazard site. When planning the layout, the fire separation distances between the facilities in the station and between the facilities in the station and the buildings outside the station should comply with the relevant regulations $[4,5]$. The fire separation distance shall be calculated according to the shortest distance between the outer walls of adjacent buildings and structures and the outer walls of storage tanks. The process equipment in the station should be arranged outdoors. The equipment area includes combustible gas unloading, compression, storage and filling devices.

The general layout should be adapted to local conditions as much as possible, so that the devices and facilities are arranged compactly. On the premise of ensuring the minimum fire safety distance and smooth traffic organization, the land utilization rate and added value in the station are improved. The combined Hydrogen and CNG refueling station is mainly an external service place, and its setting should fully meet the needs of vehicle refueling and traffic safety. 


\subsection{Requirements for explosion hazardous areas}

Researching "Code for Design of Electrical Installations in Explosive Hazardous Environments"[6] and other related codes[4, 5], the division of explosion hazard areas plays an important role in the construction and safe operation of the combined stations. The space within

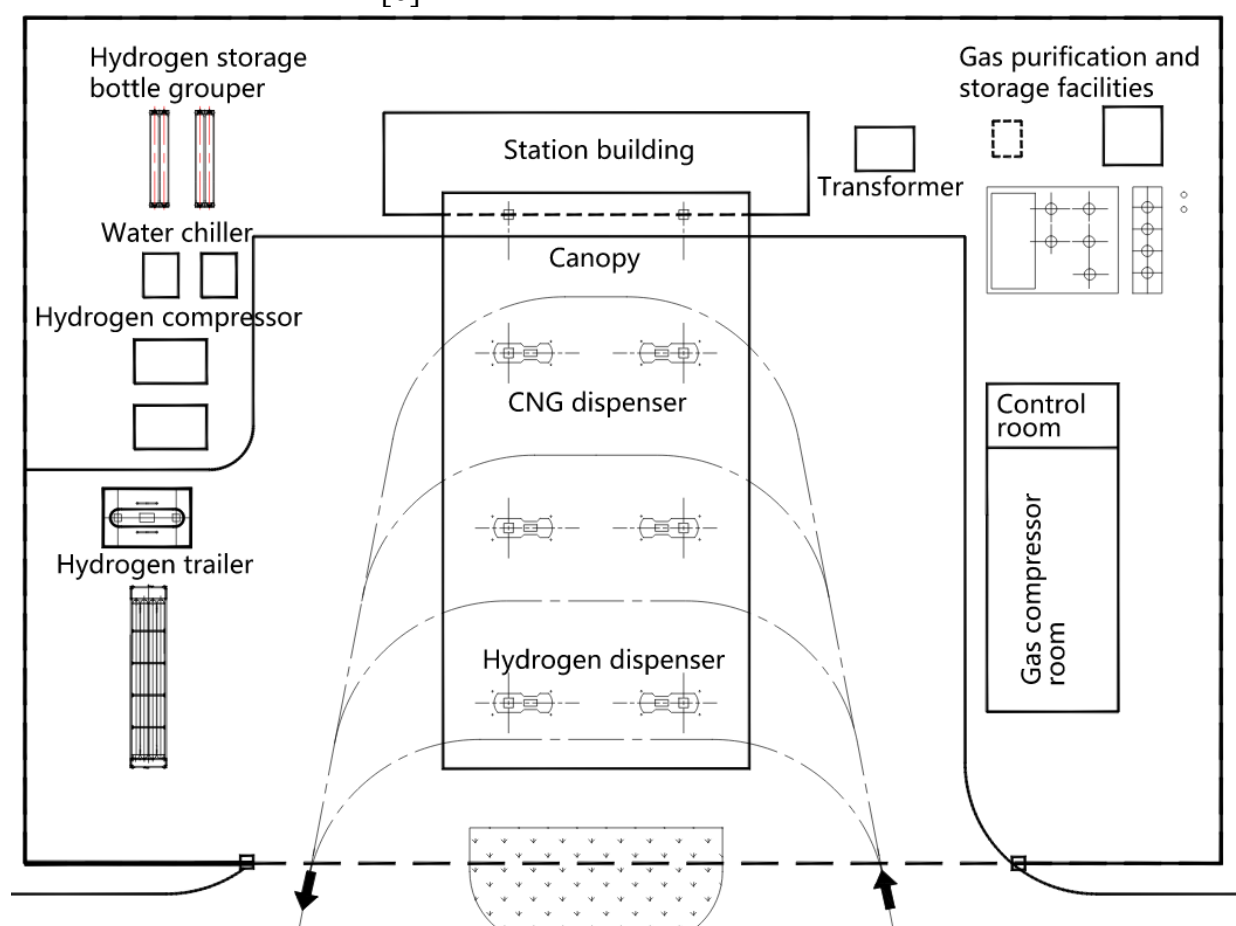

Figure 1. The layout plan of combined hydrogen and pipeline gas refueling station

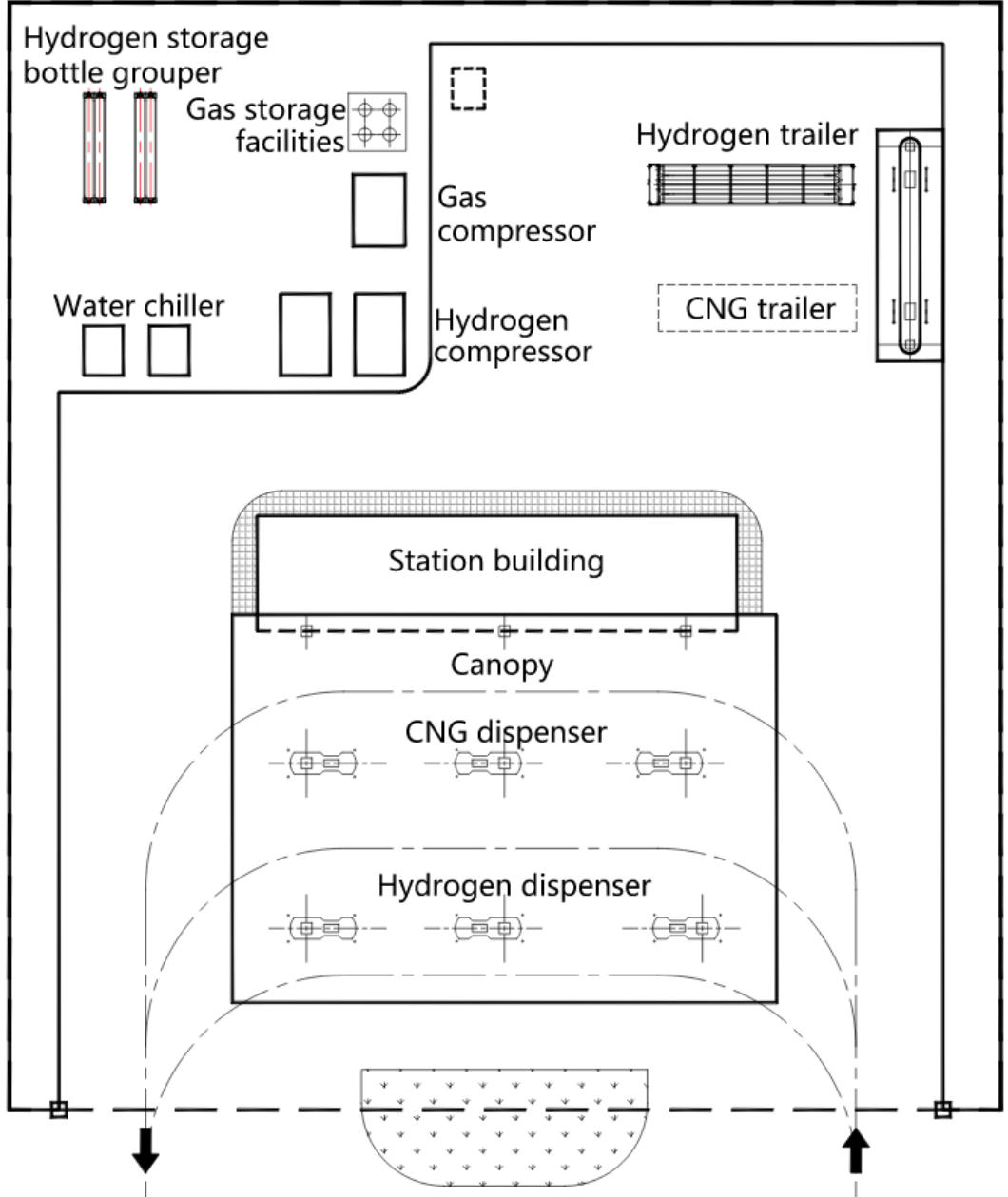

Figure 2. The layout plan of combined hydrogen and CNG secondary filling station 
$4.5 \mathrm{~m}$ from the shell of the outdoor $\mathrm{CNG}$ storage facility, from the outer wall of the CNG dispenser, and within $4.5 \mathrm{~m}$ from the shell of the outdoor CNG compressor in the horizontal direction and extending to the ground, is divided into 2 zones [4, 6]. The area with a radius of $4.5 \mathrm{~m}$ from the outer contour line of the hydrogen dispenser, hydrogen storage facilities and skid-mounted hydrogen compressor unit, as well as the edges of the doors and windows between the hydrogen compressors, is divided into 2 zones [5, 6]. Explosion hazardous area Zone 2 refers to an environment where explosive gas mixtures are unlikely to occur during normal operation, or where explosive gas mixtures only exist for a short time even if they occur.

The reasonable division of explosion-hazardous areas is helpful for the layout of production equipment and the correct selection and installation of electrical equipment in hazardous environments. The explosion hazard area of the process equipment in the station shall not exceed the boundary wall of the station area and the land use boundary, and there shall be no process facilities within $4.5 \mathrm{~m}$ of the fence.

\subsection{Land area of the combined station}

According to the above method, the general layout of the combined station is carried out, the results are shown in Figure 1 and Figure 2. For the combined hydrogen and pipeline gas refueling station with a total hydrogen storage tank capacity not exceeding $1000 \mathrm{~kg}$ and $\mathrm{CNG}$ storage not exceeding $12 \mathrm{~m}^{3}$, the total land area is not less than $5000 \mathrm{~m}^{2}$. For the combined hydrogen and CNG secondary filling station with a total hydrogen storage tank capacity not exceeding $1000 \mathrm{~kg}$ and $\mathrm{CNG}$ storage not exceeding $18 \mathrm{~m}^{3}$, the total land area shall not be less than $4000 \mathrm{~m}^{2}$. According to the station data of independent hydrogen refueling stations (off-site hydrogen production) that have been built, the total land area is $2000 \sim 4500 \mathrm{~m}^{2}$. The total area of a general-scale pipeline gas filling station is about $5000 \mathrm{~m}^{2}$ (the design supply scale is $2 \sim 4 \times 10^{4} \mathrm{~m}^{3} / \mathrm{d}$ ). The total area of CNG secondary filling station is about $3500 \mathrm{~m}^{2}$ (the design supply scale is $1 \sim 2 \times 10^{4} \mathrm{~m}^{3} / \mathrm{d}$ ).

Therefore, the combined hydrogen and $\mathrm{CNG}$ refueling model can effectively reduce the land area and increase the land utilization rate. The layout of the scheme in this paper is relatively compact. In actual engineering, taking into account the topographic characteristics and vertical design of the site, as well as the influence of combustible gas cloud diffusion distance, explosion and jet heat radiation, the total land area of different types of hydrogen and CNG refueling stations should be greater than $5000 \mathrm{~m}^{2}$ and $4000 \mathrm{~m}^{2}$ respectively.

\section{Conclusions and recommendations}

Adding hydrogen refueling facilities to the gas refueling station is an important way to accelerate the construction of hydrogen refueling stations. It can well solve the land problem and planning and layout problems of the newlybuilt hydrogen refueling station, and can promote the complementary benefits of hydrogen refueling and gas refueling. This paper studies the construction plan and scale of the combined station, puts forward the requirements for the general layout and the explosion hazard area, and designs the general layout of the combined station.

The related codes had clarified that hydrogen refueling and gas refueling stations can be jointly built, but a limit on the total storage capacity of $1000 \mathrm{~kg}$ of hydrogen is given, which is not conducive to the development and promotion of combined stations. It is recommended to increase the setting standards for total hydrogen reserves. In addition, because the system is not sound enough, there will be corresponding difficulties in planning, project initiation, approval, and operation supervision during the construction of hydrogen and $\mathrm{CNG}$ refueling stations. It is recommended that with the support of the government, formal hydrogen refueling station approval and supervision management measures be issued as soon as possible.

\section{Acknowledgments}

The author thanks the entire research team for their collaboration, including CCTEG Chongqing Engineering CO., LTD. Chongqing College of Architecture and Technology provided support to initiate this research work We also want to express our gratitude to the reviewers, whose valuable comments have greatly improved this article.

\section{References}

1. Zhenhong, L., Joan, Ogden, Yueyue, F. The fueltravel-back approach to hydrogen station siting. International Journal of Hydrogen Energy, 33: 30963101 (2008)

2. Hyunjoon, K., Myungeun, E. Development of strategic hydrogen refueling station deployment plan for Korea. International Journal of Hydrogen Energy, 45: 19900-19911 (2020)

3. Jianxin, M., Shaojun, L., Wei, Z. Comparison and selection of hydrogen transportation options for hydrogen refueling stations. Journal of Tongji University, 31: 615-619 (2008)

4. The Ministry of Housing and Urban-Rural Development of China. Technical code for Hydrogen fuelling station. China Planning Press, Beijing (2010)

5. The Ministry of Housing and Urban-Rural Development of China. Code for design and construction of automobile gasoline and gas filling station. China Planning Press, Beijing (2014)

6. The Ministry of Housing and Urban-Rural Development of China. Code for design of electrical installations in explosive atmospheres. China Planning Press, Beijing (2014) 